\title{
Oligonucleotide Fingerprints of Antigenically Related Bovine Coronavirus and Human Coronavirus OC 43
}

\author{
$\mathrm{By}$ \\ W. Laprs and D. A. Brian \\ Department of Microbiology, The University of Tennessee, \\ Knoxville, Tennessee, U.S.A. \\ With 2 Figures
}

Accepted December 12, 1984

\begin{abstract}
Summary
Virion RNAs from the bovine enteric coronavirus and the human respiratory coronavirus $\mathrm{OC} 43$ were compared by one dimensional gel electrophoresis and by oligonucleotide fingerprinting. For each virus, approximately 55 per cent of the RNA migrated as a $6.8 \mathrm{Md}$ species, 10 per cent as a $0.68 \mathrm{Md}$ species, and 15 per cent as heterogeneous small molecular weight RNA. A sequence homology of greater than 96 per cent was observed between the $6.8 \mathrm{Md}$ species from the two viruses. The $0.68 \mathrm{Md} \mathrm{RNA}$ is apparently an intravirion, subgenomic, polyadenylated molecule based on RNAse studies, oligo(dT)-cellulose chromatography, and hybridization to a cDNA clone of the $3^{\prime}$ terminal $1.19 \mathrm{~Kb}$ region of the bovine coronavirus genome.
\end{abstract}

\section{Introduction}

The bovine enteric coronavirus (BCV) causes a severe enteritis in young calves (18). The human respiratory coronavirus OC43 (HCV OC43) causes only a mild upper respiratory disease in humans of all ages (16). Recent evidence suggests that these viruses are structurally closely related. Both agglutinate erythrocytes from mice, rats, and chickens $(10,15,19)$, and both share antigens as determined by immunofluorescence (20). No biological or structural data exists to rigorously differentiate between these viruses. Because a significant fraction of the human population ( 7 to 69 per cent) both in Europe and the United States carry antibodies that are able to neutralize, immunoprecipitate, and indirectly immunofluoresce the bovine coronavirus (22), the possibility exists that the bovine coronavirus 
and the human coronavirus $\mathrm{OC} 43$ are two names for the same virus with zoonotic potential.

In this report we describe studies designed to oompare genome sequences between the two viruses. The bovine coronavirus (Mebus strain) and the human respiratory coronavirus $\mathrm{OC} 43$, when grown on the same human cell line, share a sequence homology of greater than 96 per cent as determined by $\mathrm{T}_{1}$ oligonucleotide fingerprinting but each possess unique oligonucleotides and are thus distinctly different viruses. Both viruses incorporated a significant amount of subgenomic $0.68 \mathrm{Md} \mathrm{RNA}$ late in the replication cycle and this may have implications for viral RNA sequence analyses.

\section{Materials and Methods}

\section{Gells and Viruses}

The human rectal adenocarcinoma cell line HRT-18 (23) was obtained from J. Laporte, France, and was grown as monolayers in Dulbeceo Modified Eagle Medium containing $50 \mu \mathrm{g}$ gentamicin per $\mathrm{ml}$ and 5 per cent fetal calf serum (Sterile Systems, Logan, Utah) heat inactivated at $56^{\circ} \mathrm{C}$ for 30 minutes. The Mebus strain of $\mathrm{BCV}$ $(11,19)$ which had undergone approximately 60 passages in tissue culture was cloned by four successive isolations from single plaques. The human respiratory coronavirus OC43 which had undergone seven passages in human embryonic tracheal organ culture and 15 passages in suckling mouse brain (16) was obtained from S. Weiss, University of Pennsylvania, Philadelphia, Pennsylvania, and was cloned by two successive isolations from single plaques. For each virus, a clone was passaged twice at a multiplicity of $<0.1 \mathrm{PFU}$ per cell, and then viral stocks were prepared from passages 3 through 6 by infecting cells at a multiplicity of approximately 0.5 PFU per cell. Viral titers ranging from $10^{7} \mathrm{PFU}$ per $\mathrm{ml}$ for $\mathrm{OC} 43$ to $10^{8} \mathrm{PFU}$ per $\mathrm{ml}$ for $\mathrm{BCV}$ were obtained in stock virus preparations.

\section{Radiolabeling and Purification of Virus}

Confluent monolayers of cells grown in $150 \mathrm{~cm}^{2}$ flasks were infected with a multiplicity of 1-5 PFU per cell, rinsed, and fed with $20 \mathrm{mls}$ per flask of medium containing 10 per cent normal phosphate concentration, 20 per cent fetal calf serum and $50 \mu \mathrm{Ci}$ of ${ }^{32} \mathrm{Pi}$ per $\mathrm{ml}$. Infected cells were incubated $72-96$ hours at $37^{\circ} \mathrm{C}$ and virus was purified from supernatant fluids as described previously (2) except that sucrose was dissolved in TMEN (50 mM Tris-acid maleate $[\mathrm{pH} 6], 0.1 \mathrm{M} \mathrm{NaCl}, 1 \mathrm{~mm}$ EDTA).

\section{Analysis of RNA}

RNA was extracted from purified virus using SDS, proteinase $K$ and phenol as described previously (2).

For electrophoretic analysis virion RNA was denatured in glyoxal and dimethylsulfoxide, and electrophoresed on 1 per cent agarose gels in a vertical slab apparatus of $10 \mathrm{~cm} \times 14 \mathrm{~cm} \times 3 \mathrm{~mm}$ dimensions using the method of MoMASTER and CARMICHAEL (17). Gels were dehydrated in two successive 30 minutes baths of 100 per cent methanol, compressed by blotting to a thickness of $<1 \mathrm{~mm}$, and exposed to X-Omat film.

For $\mathrm{T}_{1}$-oligonucleotide fingerprint analysis virion genomic RNA species were isolated by rate zonal sedimentation on preformed linear gradients of 30 to 15 per 
cent (wt/wt) sucrose containing 0.1 per cent SDS, 0.02 M Tris-hydrochloride, $\mathrm{pH} 7.4$, $0.1 \mathrm{~m} \mathrm{NaCl}$, and 0.001 м EDTA, for 1.5 hours at $110,000 \times g$ in a Sorvall 650 rotor, at $25^{\circ} \mathrm{C}$. Fractions $(0.2 \mathrm{ml})$ were collected and the distribution of radioactivity was determined by Cerenkov radiation. RNA was precipitated at $-20^{\circ} \mathrm{C}$ for 16 hours by adding 2 volumes of 100 per cent ethanol and 0.1 volume of $2 \mathrm{~m}$ sodium acetate. RNA was digested to completion with RNAse T1 and electrophoresed in two dimensions on polyacrylamide gels according to the method of DEWACHTER and FIERS (5) as modified by Chewtex et al. (3).

\section{Results}

\section{Virion $R N A$}

Experiments in which BCV RNA was labeled with $\left[{ }^{3} \mathrm{H}\right]$-uridine for the first 48 hours postinfection and electrophoretically analyzed on formaldehyde-agarose gels revealed only a high molecular weight species that

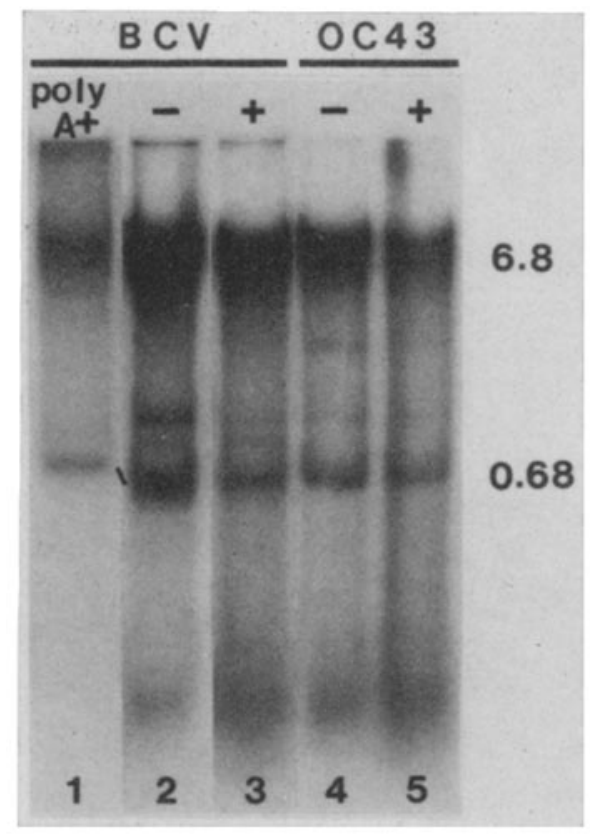

Fig. 1. Agarose gel electrophoresis of virion RNA after glyoxal-dimethylsulfoxide denaturation. Lanes: 1 BCV RNA that bound to oligo (dT) cellulose (Type 7, PL Biochemicals, Inc.) under conditions of $0.12 \mathrm{~m} \mathrm{NaCl}, 0.01 \mathrm{M}$ Tris HCl (pH 7.5), 1 mar EDTA, 0.2 per cent SDS and eluted with water; 2 BCV RNA from purified virus; 3 BCV RNA from virus treated with $20 \mu \mathrm{g}$ bovine pancreatic ribonuclease A (Sigma) per $\mathrm{ml}$ for 1.5 hours at $37^{\circ} \mathrm{C}$ prior to virus purification; 4 OC43 RNA from purified virus; $5 \mathrm{HCV}$ OC $43 \mathrm{RNA}$ from virus treated with $20 \mu \mathrm{g}$ bovine pancreatic ribonuclease $\mathrm{A}$ (Sigma) per $\mathrm{ml}$ for 1.5 hours at $37^{\circ} \mathrm{C}$ prior to virus purification. 6.8 and 0.68 refer to molecular weight $\times 10^{-6}$. Percentage composition was determined by slicing the radioactive bands from the agarose, using the autoradiogram as a template, and counting the gel slices in Scintiverse (Fisher) 
comigrated with porcine transmissible gastroenteritis virus genomic RNA (2, and data not shown). BCV genomic RNA therefore has a molecular weight of approx imately $6.8 \times 10^{6}$. When virion RNA from both $\mathrm{BCV}$ and OC43 was labeled in vivo with ${ }^{32} \mathrm{P}$-orthophosphate for 72 to 96 hours postinfection and analyzed on denaturing glyoxal-agarose gels, approximately 55 per cent from each virus migrated as a $6.8 \times 10^{6} \mathrm{M}$.W. species (Fig. 1). Approximately 10 per cent migrated as a distinct species with an electrophoretic mobility close to that of $18 \mathrm{~S}$ ribosomal RNA and therefore had an apparent molecular weight of $0.68 \times 10^{6}$ (Fig. 1). Approximately 15 per

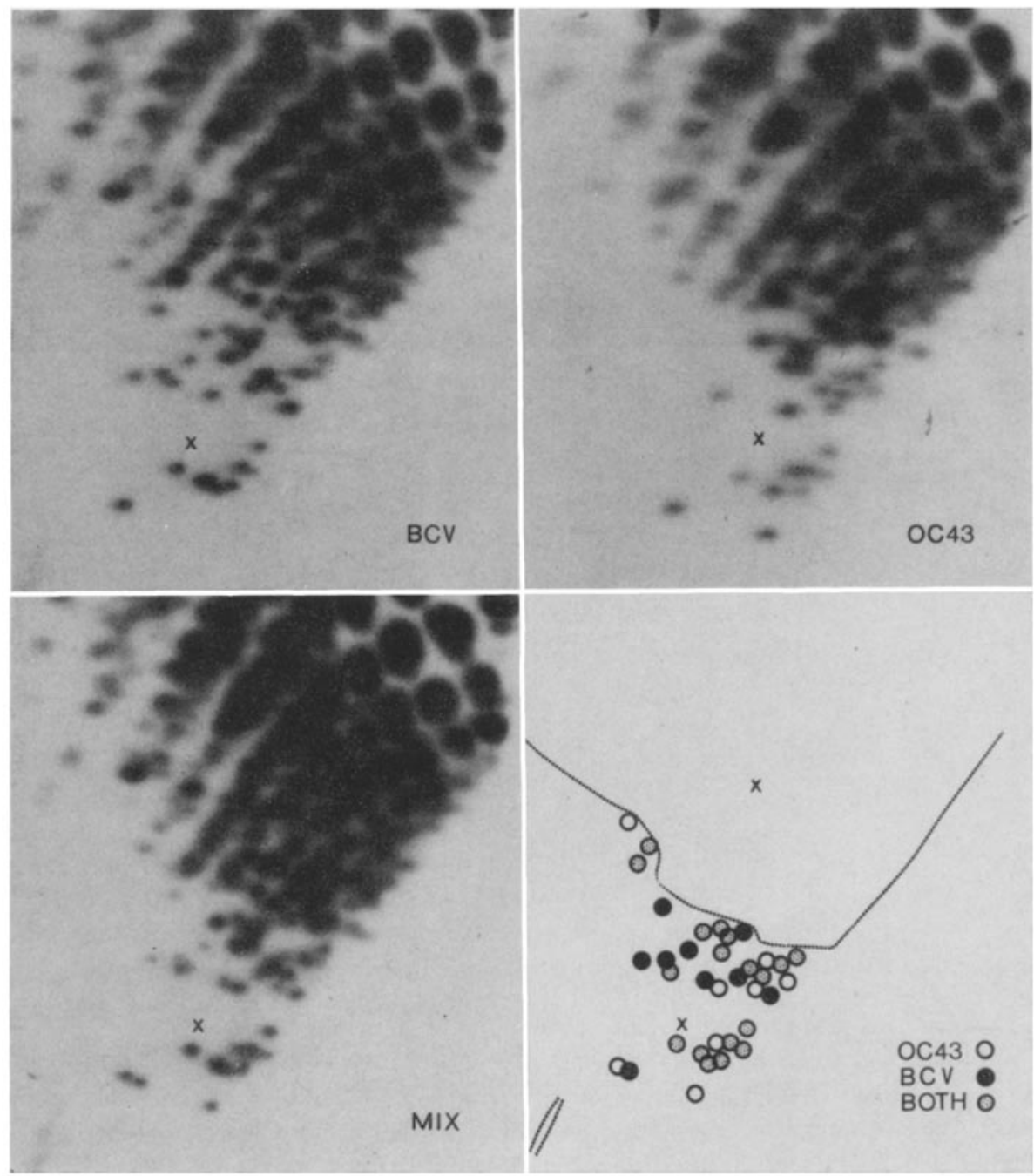

Fig. 2. Oligonueleotide fingerprints of $\mathrm{BCV}$ and HCV OC43 genomic RNAs. 1 to 3 $\times 10^{5}$ Cerenkov counts were used per gel. Spots common to both viruses, as determined by a mixing experiment, are hatched in the schematic diagram 
cent of the RNA from each virus migrated as heterogeneous small molecular weight RNA between $4 \mathrm{~S}$ and $18 \mathrm{~S}$ in size. The remainder of the RNA was heterogeneous and was distributed throughout the gel.

\section{Genome Sequence Homology as Determined by Oligonucleotide Fingerprinting}

To measure the degree of relatedness between $\mathrm{BCV}$ and $\mathrm{HCV} \mathrm{OC} 43$, high molecular weight genomic RNA was isolated for each virus by rate zonal sedimentation in sucrose gradients, fingerprinted separately, and then as a mixture using an equal number of counts (Fig. 2). Inspection revealed a high degree of similarity between the two viruses consistent with earlier reports of close antigenic relatedness $(6,20)$ and our own recent work $(9)$. Of the 27 large resolvable oligonucleotides for $\mathrm{BCV}, 9$ were unique to $\mathrm{BCV}$, and of the 26 large resolvable oligonucleotides for $\mathrm{HCV}$ OC 43, 8 were unique to HCV OC43. 18 oligonucleotides were in common and represent a comigration of 66-69 per cent of the large oligonucleotides. Assuming that sequence homology demonstrated in the large oligonucleotides is representative of the remaining genome, we conclude there is a common nucleotide sequence of greater than 96 per cent between the two virus genomes based on computer simulation of $T_{1}$ oligonucleotide mapping (1).

\section{Properties of the Virion 0.68 Md Species}

Incubating virus with pancreatic ribonuclease prior to purification, under conditions that completely destroy the integrity of ribosomal RNA, failed to destroy the $0.68 \mathrm{Md}$ RNA (Fig. 1). From this we conclude the species is intravirion. The $0.68 \mathrm{Md} \mathrm{RNA}$ from $\mathrm{BCV}$ annealed to oligo(dT) cellulose indicating that it is polyadenylated (Fig.1) and annealed to ${ }^{32} \mathrm{P}$-labeled cloned cDNA representing the $3^{\prime}$ terminal $1.19 \mathrm{~Kb}$ sequence of $\mathrm{BCV}$ genomic RNA (data not shown) indicating that this RNA is either an encapsidated subgenomic virus mRNA or possibly a defective genome of the type described for defective interfering particles of other positive-strand viruses.

\section{Discussion}

Our studies demonstrate that $\mathrm{BCV}$ (Mebus strain) and $\mathrm{HCV} \mathrm{OC} 43$ can both be grown on the human rectal adenocarcinoma cell line (HRT-18). Other strains of BCV, including an isolate from France (13), the LY-138 strain (8) and a primary isolate from the University of Tennessee, College of Veterinary Medicine (our unpublished observations), and HCV OC43-like viruses (14) can also grow on these cells without adaptation. Because the HRT-18 cells retain many properties of differentiated tissue cells (23), these observations are consistent with the notion that there is no rigid species restriction on the growth of these coronaviruses and that they may have zoonotic potential. BCV reportedly caused diarrhea in one investigator and the virus was reisolated from this person (22). 
Our studies further establish that BCV (Mebus strain) and HCV OC43, although similar, are not identical viruses. The cytopathic effects caused by $\mathrm{BCV}$ and HCV OC43 are not identical (data not shown). BCV causes a foamy appearance of the cell cytoplasm and a clumping of infected cells and HCV OC43 causes a disintegration of the cell into small pieces. Both cause small $(1-2 \mathrm{~mm})$ opaque plaques under agar and both can be detected by hemadsorption following agar removal. No difference in size can be detected between the genomes of $\mathrm{BCV}$ and $\mathrm{HCV}$ OC43 by one-dimensional gel electrophoresis of glycosylated RNA. The genome for both viruses therefore measures approximately $6.8 \times 10^{6} \mathrm{M}$.W. since the genome of BCV comigrates with the $6.8 \times 10^{6} \mathrm{M} . W$. genome of the porcine transmissible gastroenteritis virus in agarose gels after being denatured with formaldehyde (2 and data not shown).

The comparative analysis of oligonucleotide fingerprints between the $\mathrm{BCV}$ and $\mathrm{HCV}$ OC43 genome RNAs suggests they have a sequence divergence of 3-4 per cent. The exact degree of divergence cannot be determined using this technique since the large oligonucleotides probably represent less than 10 per cent of the entire genome, but clearly these are not identical viruses. A sequence divergence of 3-4 per cent is consistent with a distinct difference in the behavior of 3 of the 4 homologous proteins we observe between the two viruses $(9)$.

In preparations of $\mathrm{BCV}$ and $\mathrm{HCV}$ OC43 labeled with ${ }^{32} \mathrm{P}$ orthophosphate for $72-96$ hours we found a $0.68 \times 10^{6} \mathrm{M}$.W. species representing 10 per cent of total virion RNA. For BCV we have shown this to be intravirion, polyadenylated, and subgenomic. Its function is unknown. It was not detected in earlier studies on $\mathrm{BCV}$ that employed ${ }^{3} \mathrm{H}$-uridine for labeling periods of less than 48 hours (7). Since our studies here use labeling periods of greater than 48 hours it is possible that the $0.68 \times 10^{6}$ M.W. species becomes incorporated only late in infection and may represent adventitious encapsidation of a viral subgenomic messenger RNA of the type described for several coronaviruses $(4,12,21)$. Further studies are needed to confirm this interpretation.

\section{Acknowledgements}

This work was supported by Public Health Service grant R01-AI-14367 from the National Institutes of Health. W. L. is a predoctoral trainee on grant T 32-AI07123 from the National Institutes of Health.

\section{Reierences}

1. Aaronson, R. P., Young, J. F., Parese, P.: Oligonucleotide mapping: evaluation of its sensitivity by computer-simulation. Nucleic Acids Res. 10, 237-246 (1982).

2. Brian, D. A., Dennis, D. E., GUY, J. S.: Genome of porcine transmissible gastroenteritis virus. J. Virol. 34, 410-415 (1980). 
3. Clewley, J. P., Gentsch, J., Bishop, D. H. L.: Three unique viral RNA species of snowshoe hare and La Crosse bunyaviruses. J. Virol. 22, 459-468 (1977).

4. Dennis, D. E., Brian, D. A.: RNA-dependent RNA polymerase activity in coronavirus-infected cells. J. Virol. 42, 153-164 (1982).

5. DeWachter, R., Fimes, W.: Preparative two-dimensional polyacrylamide gel electrophoresis of ${ }^{22}$ P-labeled RNA. Anal. Biochem. 49, 184-197 (1972).

6. Gerka, G., Cereda, P. M., Grazia-Revelio, M., Cattaneo, E., Gattachia, M., Torseluxnt-Gerna, M.: Antigenic and biological relationships between human coronavirus OC43 and neonatal calf diarrhoea coronavirus. J. gen. Virol. 54, $91-102(1981)$.

7. GUY, J. S., BRIAN, D. A. : Bovine coronavirus genome. J. Virol. 29, 293-300 (1979).

8. HAJER, I., SToRz, J.: Structural polypeptides of the enteropathogenic bovine coronavirus strain LY-138. Arch. Virol. 59, 47-57 (1979).

9. Hogue, B. G., King, B., Brian, D. A. : Antigenic relationships among proteins of bovine coronavirus, human respiratory coronavirus $\mathrm{OC} 43$, and mouse hepatitis coronavirus A 59. J. Virol. 51, $384-388$ (1984).

10. Kapikian, A. Z., James, H. D., Keliy, S. J., Ktvg, L. M., VAughn, A. L., Chancock, R. M.: Hemadsorption by coronavirus strain OC43. Proceedings of the Society of Experimental Biology and Medicine 139, 179-186 (1972).

11. KING, B., Brian, D. A.: Bovine coronavirus structural proteins. J. Virol. 42, $700-707(1982)$.

12. Lar, M. C., Brayton, P. R., Armen, R. C., Patton, C. D., Pugh, C., Stohlmai, S. A.: Mouse hepatitis virus A59: mRNA structure and genetic localization of the sequence divergence from hepatotropie strain MHV-3. J. Virol. 39, 823-834 (1981).

13. Laponte, J., Bobulesco, P.: Polypeptide structure of bovine enteric coronavirus: comparison between a wild strain purified from feces and a HRT 18 cell adapted. strain. Adv. Exp. Med. Biol. 142, 171-179 (1981).

14. Macnaughton, M. R.: Occurrence and frequency of coronavirus infections in humans as determined by enzyme-linked immunosorbent assay. Int. Immun. 38, $419-423(1982)$.

15. McIntosh, K.: Coronaviruses: a comparative review. Curr. Top. Microbiol. Immunol. 63, 85-129 (1974).

16. MoIntosh, K., Kapikian, A. Z., Hardison, K. A., Hartuey, J. W., Chanock, R. M.: Antigenic relationship among the coronaviruses of man and between human and animal coronaviruses. J. Immunol. 102, 1109-1118 (1969).

17. MoMaster, G. K., Carmtohazi, G. G.: Analysis of single and double-stranded nucleic acids on polyacrylamide and agarose gels by using glyoxal and acridine orange. Proc. Natl. Acad. Sci. U.S.A. 74, 4835-4838 (1977).

18. Mebus, C. A.: Pathogenesis of coronavirus infections in calves. Am. J. Vet. Res. 173, $631-632$ (1978).

19. Mebus, C. A., Statr, E. L., Rhodes, M. B., Twtehaus, M. J.: Neonatal calf diarrhea: propagation, attenuation, and characteristies of a coronavirus-like agent. Am. J. Vet. Res. 34, 145-150 (1973).

20. Pedergen, N. C., Wark, J., Mengeling, W. L.: Antigenic relationship of the feline infectious peritonitis virus to coronaviruses of other species. Arch. Virol. a8, 45-53 (1978).

21. STerN, D. F., KenNedy, S. T. T.: Coronavirus multiplication strategy. I. Identification and characterization of virus-specified RNA. J. Virol. 34, 665-674 (1980). 
22. SToRz, J., Rort, R.: Reactivity of antibodies in human serum with an enteropathogenic bovine coronavirus. Med. Microbiol. Immunol. 169, 169-178 (1981).

23. Tomorkins, W. A. F., Watrach, A. M., Sommale, J. D., Sehutze, R. M., Harris, J. A. : Cultural and antigenic properties of newly established cell strains derived from adenocarcinomas of the human colon and rectum. J. Natl. Canc. Inst. 52, $1101-1106(1974)$.

Authors' address: Dr. D. A. BRIAN, The University of Tennessee, Department of Microbiology, Walters Life Seience Building, Knoxville, TN 37996-0845, U.S.A.

Received November 30,1984 